Article

\title{
How Social Capital Affects the Quality Performance of Agricultural Products: Evidence from a Binary Perspective of China
}

\author{
Shaoling Fu ${ }^{1}$, Hua Liu ${ }^{1}$, Kim Hua Tan ${ }^{2}{ }^{\mathbb{D}}$, Yuanzhu Zhan ${ }^{3}$, Yalan Ding ${ }^{1}$ and Wene Qi ${ }^{1, *}$ \\ 1 College of Economics \& Management, South China Agricultural University, Guangzhou 510642, China; \\ lfbfu@scau.edu.cn (S.F.); liuhua301415@stu.scau.edu.cn (H.L.); dingyalan@stu.scau.edu.cn (Y.D.) \\ 2 Business School, University of Nottingham, Nottingham NG8 1BB, UK; Kim.Tan@nottingham.ac.uk \\ 3 Management School, University of Liverpool, Liverpool L69 7ZH, UK; yuanzhu.zhan@liverpool.ac.uk \\ * Correspondence: qiwene@scau.edu.cn or qiwenescau@163.com; Tel.: +86-133-9262-1688
}

Received: 30 July 2018; Accepted: 22 August 2018; Published: 24 August 2018

\begin{abstract}
Improving the quality of agricultural products is the key factor in promoting agricultural development in the Belt and Road program. Although many studies have investigated the relationship between social capital and performance, the findings are inconsistent. Moreover, the mechanism of how social capital affects the quality performance of agricultural products remains unclear. Accordingly, this study developed a theoretical model with propositions from a social capital-quality performance of agricultural products paradigm for examining and comparing the three dimensions of social capital: The relationships among cognitive (measured by shared values), relational (measured by reciprocity) and structural (measured by communication), and their role in ensuring quality performance of agricultural products from the company and farmer perspectives. This study selected the companies and farmers in "A company + farmers" model. The data analysis is based on a sample of 184 companies and 414 farmers. The results show that shared values and communication have a significant positive effect on reciprocity. In terms of the influence on reciprocity, communication is higher than shared values from both the corporate and farmer perspectives. The three dimensions of social capital have different effects on quality performance of agricultural products. On the company side, communication and reciprocity in social capital have a significant positive effect on the quality performance of agricultural products, with the order of effect being communication first followed by reciprocity. On the farmer side, reciprocity and shared values have a significant positive effect on the quality performance of agricultural products, with the order of effect being reciprocity first followed by shared values. These findings have positive theoretical and practical significance for companies and farmers aiming to improve the quality of agricultural products.
\end{abstract}

Keywords: Belt and Road; quality performance of agricultural products; social capital; binary perspective; China

\section{Introduction}

Improving the quality of agricultural products in an important issue in the context of globalization. In most developing countries such as India, Thailand and China, the development of agriculture is experiencing a much more rapid evolution than anywhere in the world. In 2013, the Chinese government initiated the so-called 'Belt and Road' strategy which aims to develop the world's largest platform for economic cooperation. In particular, both sea and land roads formed by the "Belt and Road" provide a broad market space for China's agricultural product exports and agricultural development as well as paving the way for the globalization of China's agricultural sector. Although 
agriculture faces tremendous opportunities for development, in reality, stringent entry barriers to foreign markets, such as "trade barriers and green barriers", still limit the exportation of Chinese agricultural products. Therefore, findings ways to improve the quality of agricultural products is the key for agricultural enterprises to gain global competitive advantages.

In China, the "A company + farmers" $(\mathrm{C}+\mathrm{F})$ model is the dominant model adopted to ensure quality performance [1] and is also an important organizational mode for the development of agricultural industrialization [2]. This model refers to the companies' initiative to find farmers willing to sign cooperative management contracts; in addition, the company is mainly responsible for helping farmers produce agricultural products, including providing technical services; distributing excellent breeding; acquiring, processing, and selling agricultural products; and formulating market strategies to avoid market risks, and so on. Under this model, farmers are mainly responsible for ensuring the rational and standardized production of agricultural products, meeting production standards, responding to production risks, handing over agricultural products to the company, and generating income. The relationship between the company and the farmer in $\mathrm{C}+\mathrm{F}$ is the upstream relationship in the supply chain: As a supplier, the farmer supplies the product or resources to the company, and as a buyer, the company purchases the agricultural products or resources produced by the farmer according to the contract price. In practice, the cooperation in this mode is mainly in a loose and semi-closed state, and the short-term goal is obvious. It is not conducive to effective long-term cooperation, e.g., the improvement of quality performance of agricultural products.

Social capital plays an important role in agricultural economies, including by sustaining capacity for collective action, lowering transaction costs in contracting via trust, and offering access information via networks of contacts [3-5]. According to Johnson et al. [3], agriculture firms can improve their economic performance by investing in the social capital which can lead to higher firm-level returns than in the human or physical capital. Social capital is a "relationship glue" that effectively supports supply chain partnerships and helps companies enhance their competitive advantage and promote performance [5,6]. In practice, companies have realized the benefits of social capital in supply chain management. For example, Dell (a personal computer manufacturer) and its suppliers seamlessly communicate quality, design and production requirements as well as inventory levels through real-time information systems to promote production. Toyota (an automotive manufacturer) forms a good network of relationships with its major suppliers, thus achieving effective cooperation [7]. Many researchers have also recognized the positive effects of social capital on performance by exploring how social capital is created and how it can affect strategic performance [8-10] or operational performance (e.g., cost, flexibility, satisfaction, etc.) [6,11-15].

Although many studies have investigated the relationship between social capital and performance, the findings are inconsistent. For example, Villena et al. [9] argue that social capital has a certain negative impact on performance. Moreover, the mechanism on how social capital affects the quality performance of agricultural products remains unclear. In China, the special culture characterized by collectivism and relationship networks prompts enterprises and individuals to pay extra attention to informal relationships [16], which also provide a fertile foundation to study the impact of social capital on the quality performance of agricultural products $[17,18]$. The current study subdivides social capital into three dimensions: Structural, cognitive, and relational, aims to address the following research questions:

(1) What are the relationships among the three dimensions of social capital?

(2) How do the three dimensions of social capital affect the quality performance of agricultural products?

This study selected the companies and farmers in $\mathrm{C}+\mathrm{F}$ as the survey object. Based on a sample of 184 companies and 414 farmers, this study examines and compares the relationship among variables from a binary perspective, namely from companies' and farmers' perspectives. The results would help agribusiness to improve the quality performance of agricultural products. They provide significant insight into Chinese food supply chain practice and sustainable agricultural development. 
The rest of the paper is organized as follows. The second section after the introduction describes the literature review and research hypotheses, followed by the research methodology. In Section 4, the analyses and results are described, then Section 5 discusses the main findings. The last section includes the conclusion, theoretical contributions, managerial implications and future research.

\section{Literature Review and Research Hypotheses}

\subsection{Social Capital}

Social capital refers to "the sum of actual and potential resources in the network of relationships owned by individuals or social units" [17]. It is commonly understood as a valuable asset derived from the resources obtained through social relations [17]. The initial research on social capital mainly considers individuals as objects. With the deepening of research on social capital, the research object level gradually expanded to the team, organization, community, and country, especially on the organizational level. At the organizational level, enterprises are mainly taken as objects. Many scholars divide social capital according to different standards. The most mainstream division includes the internal and the external social capital of enterprises. The current study explores the external social capital of the enterprise, that is, the social capital between the company and the farmers (suppliers). The social capital theory provides a theoretical perspective for the company and farmers to gain a competitive advantage through their social networks.

Social capital has different measures. Nahapiet and Ghoshal [17] divide social capital into three dimensions, namely, structural, relational, and cognitive. These three dimensions have been applied in some studies as well $[6,9,18,19]$. This study intends to use these three dimensions in measuring social capital.

Shared values have been widely regarded as the key part of the cognitive dimension [20], and the cognitive dimension represents the common goals and values among doers. The structural dimension refers to the mode of communication among different sides, that is, the people who first meet one another and the process of communication among them [21]. These social relationships among contacts are likely to generate valuable information [22]. The previous literature has examined the dimensions of communication, social interaction, and information sharing. The relational dimension enables organizations to manage the relationships through trust rather than strict formal contracts; it is closely related to trust, reciprocity rules, responsibilities, and relationships [23,24], includes the aspects of reciprocity, trust, respect, friendship, commitments, and other dimensions. These three dimensions reflect the organization's valuable assets because they enable the latter to exchange information, knowledge, and other capital through social networks and connections [24]. This study aims to measure cognitive, structural, and relational dimensions through shared values, communication, and reciprocity.

\subsection{The Relationship among the Three Dimensions of Social Capital}

The three dimensions of social capital are mutually influential $[5,6,9,18,19]$. Cognitive and structural dimensions are regarded as preposition variables of relational dimension $[6,25,26]$. Villena et al. [9] reported that the relational dimension has a higher impact on performance than the structural and cognitive dimensions. Therefore, we select the relational dimension as the core variable of social capital to explore the influence of structural and cognitive dimensions on the relational dimension.

This study suggests shared values have a positive effect on reciprocity. When the values between the buyer and the supplier are inconsistent, they are prone to misunderstanding [20,24]. In comparison, the supply chain partners with shared values can understand each other, which is conducive to their sense of identity when they follow a certain code of conduct, and to achieve collective goals, they are inclined to interact and reciprocate each other [27,28]. In rural China, widespread social norms exist, such as religious authority, village committee authority, parental authority, and caring for children. 
The agricultural enterprises and farmers rooted in the rural areas must therefoe abide by the code of conduct of rural society to promote the cooperation of mutual benefit between companies and farmers following these norms. China is a collectivist country, in which cooperation often manifests as follows: "collective interests are higher than personal interests," "unity is power", emphasis on "mutual help", etc. Therefore, when shared values exist between the company and farmers, such commonality is beneficial for further development of cooperation and reciprocity. Thus, the following assumption is proposed:

Hypothesis 1a (H1a). Shared values positively affect reciprocity.

This study proposes that communication can promote reciprocity. Communication refers to the exchange of information related to business transactions and issues related to supply chain partners [29]. Communication encourages buyers and suppliers to jointly participate in planning, setting goals, and solving problems [30], which in turn, can help them obtain favorable information to promote collaboration and suppress the generation of opportunism [31]. However, the lack of communication increases the cost of meaningful information acquisition [9]. When exchanging information that is valuable to oneself and others, it means that the valuable information essentially helps others (i.e., reciprocity). Therefore, this study proposes that communication (structural dimension) increases the level of reciprocity (relational dimension) in the relationship between the company and farmers. Thus, we present the following hypothesis:

\section{Hypothesis $\mathbf{1 b} \mathbf{( H 1 b ) . ~ P o s i t i v e ~ c o m m u n i c a t i o n ~ a f f e c t s ~ r e c i p r o c i t y . ~}$}

\subsection{The Relationship between Social Capital and Quality Performance of Agricultural Products}

This study proposes that shared values (cognitive dimension) have a positive impact on the quality performance of agricultural products. Shared values coordinate the subjective perceptions of supply chain members on different areas, promote unity and the tacit understanding of ideas, and suppress the possibility of opportunistic behaviors [27,32]. These outcomes result in reduced supervision costs [32] and improved operational performance of the company (e.g., in terms of cost, innovation, and flexibility) $[6,15,24]$, which can be helpful in forming a common vision. However, the lack of similarity in values not only leads to setbacks but also negatively affects performance [20,33]. Therefore, having shared values encourages supply chain partners' adherence to common goals, such as the method of actively improving the quality performance. In this way, performance can be improved when the company and the farmers agree on what constitutes quality performance improvement, how to achieve this, and the obstacles that may hinder the achievement. Thus, the following assumption is proposed:

Hypothesis 2a (H2a). Shared values positively affect the quality performance of agricultural products.

Reciprocity (relational dimension) can provide benefits to both partners and subsequently achieve a win-win situation. When adhering to the principle of reciprocity, the partners shift from a role that cares for oneself to a relationship that cares for common interests and responsibilities [34,35]. Therefore, reciprocity reduces opportunistic behaviors and maintains cooperation. Conversely, the lack of reciprocity increases uncertainty in the relationship, causing members to hide related potential resources [36,37]. This action hampers cooperation between the parties involved. Once the company and the farmer forge a reciprocal relationship, they generally perform as follows: When the market price is higher than the contract price, the enterprise appropriately raises the contract price to benefit the farmers; when the market price is lower than the contract price, the farmers actively give profits to the enterprise and reduce its losses; when natural disasters and other accidents occur, the enterprise assumes part of the responsibility to help the farmers overcome the difficulties [4]. Although this 
reciprocal behavior limits each other's interests, such behavior can reduce both parties' concerns regarding future uncertainty and the other's default. This scenario indicates strong willingness to cooperate with both parties and is thus conductive to the smooth progress of the trading., Reciprocal behavior promotes long-term cooperation between the company and the farmers rather than simply obtaining short-term benefits, which can significantly reduce unnecessary costs [38] and the cost of defaults during the development of formal contracts. Thus, the following assumption is proposed:

Hypothesis $\mathbf{2 b}(\mathbf{H} \mathbf{2} \mathbf{b})$. Reciprocal positively affects the quality performance of agricultural products.

This study suggests that communication (structural dimension) can promote the quality performance of agricultural products. Communication between partners can help them obtain resources, such as information and knowledge of each other. In addition, obtaining proprietary information is essential in responding quickly to and synchronizing the processes between organizations. Moreover, communication can help members cope with uncertainty, such as the issue of information asymmetry related to cost, demand, order, and quality. The close interactions between the supplier and the enterprise help improve the accuracy of orders, reduces the turmoil of inventory, enhances the decision level, coordinates the process effectively, and improves the supply chain performance [9].

In $\mathrm{C}+\mathrm{F}$ alliance, the companies-as the communication leader-can regularly hold symposia with the geographically scattered farmers, in which the former can discuss the quality performance improvement mechanisms with the latter and help develop quality and safety supply awareness of agricultural products. They can also collect the opinions of farmers through various channels to understand their ideas, thus reducing the gap between both sides. In the event of disputes, they can actively communicate with farmers to resolve conflicts. The timely information communication between both sides can fully reduce the supervision cost of the production process [39], thus providing information security for quality performance. It is helpful to improve the quality of agricultural products. Thus, the following assumption is proposed:

Hypothesis 2c (H2c). Communication positively affects the quality performance of agricultural products.

In summary, based on the social exchange theory, this study constructs a theoretical model (see Figure 1), and proposes five hypotheses regarding the three dimensions of social capital and quality performance of agricultural products.

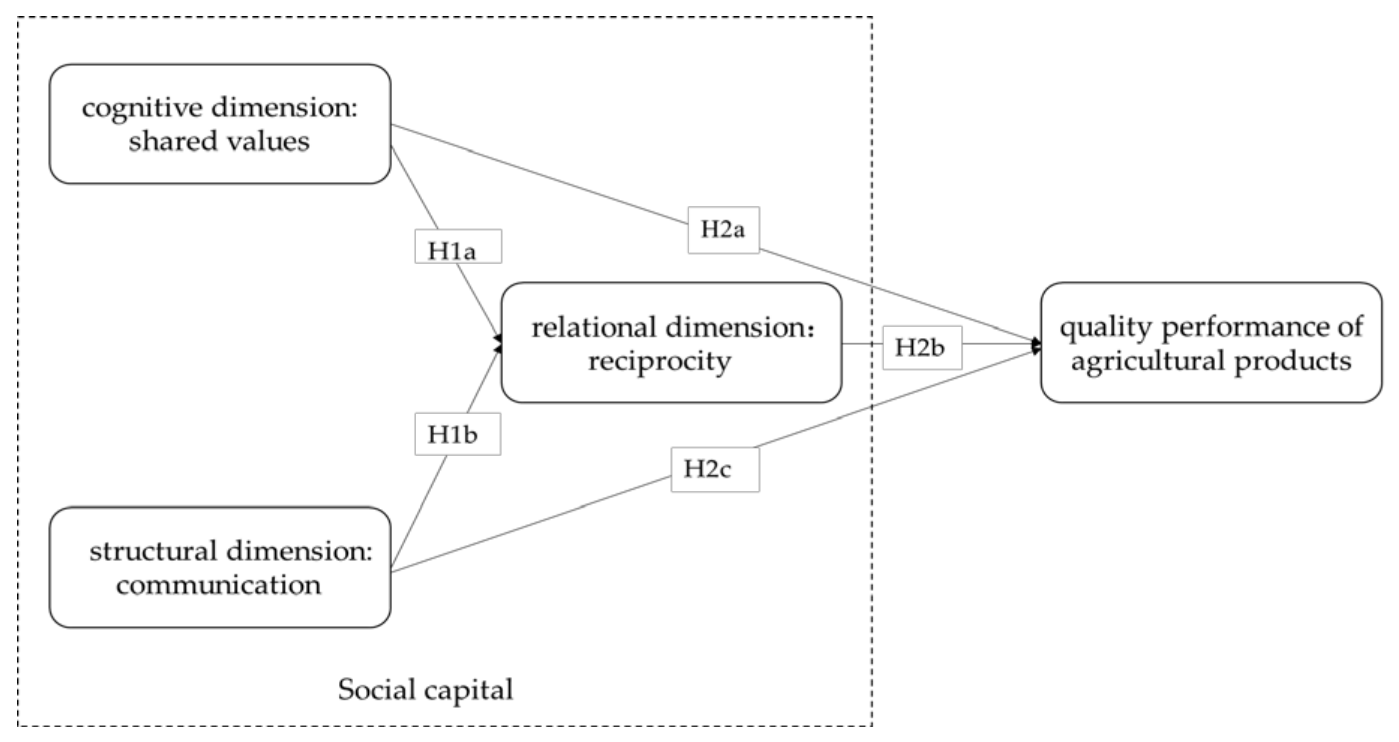

Figure 1. Theoretical Model and Research Hypothesis. 


\section{Research Design}

\subsection{Questionnaire Design}

The measurement items in the questionnaire design are adapted by combining the mature scales used by scholars. To ensure the content validity of the questionnaire and reflect in detail the situation of China's agricultural cooperation, this study actively sought the advice of experts in the field of agricultural management and the managers of agricultural enterprises. After repeated revisions and confirmation of the measurement items of each variable in the questionnaire, the final formal questionnaire was achieved.

Questionnaires were utilized to conduct data demonstration on theoretical models. The constructs were measured by a 7-point Likert scale, which 1 represents "strongly disagree", 7 represents "strongly agree". Social capital includes the three dimensions of cognitive dimension (shared values, SV), relational dimension (reciprocity, RE), and structural dimension (communication, $\mathrm{CO}$ ). Two items were measured shared values, four items for reciprocity, and four items for communication. For the quality performance of agricultural products (QP), three items adapted from Huo et al. [40] and Fu et al. [1] were used to measure it. Appendix A shows the measurement items and sources.

\subsection{Data Collection}

The samples are from the regions of Guangdong and Hainan in China. These two provinces were chosen because the two provinces enjoyed similar climates and cultivated similar agricultural products. The survey objects are the company and farmers in $\mathrm{C}+\mathrm{F}$ alliance. On the companies' side, since the survey data mainly involves cooperation information between companies and their alliance partners, key data such as shared values, communication, reciprocity, and quality performance of agricultural products are not objective data that can be obtained through external channels. Therefore, the survey chooses the senior managers who understand the internal alliance operations as the object of investigation to collect data. A total of 280 questionnaires were distributed. After excluding the invalid questionnaires (e.g., incomplete and invalid forms), a total of 184 valid questionnaires were collected, with an effective questionnaire recovery rate of $65.7 \%$. On the farmers' side, before the formal survey, 20 farmers were invited to pre-test. Based on their feedback, the questionnaire was revised to avoid ambiguous issues. The visitation and mailing methods were employed for investigation. A total of 500 questionnaires were distributed, of which 414 were valid, resulting in an effective questionnaire recovery rate of $82.8 \%$. The number of samples reached the standard for conducting empirical research. Tables 1 and 2 present the statistics of the basic characteristics of the companies and farmers, respectively.

As shown in Table 1, the number of farmers cooperated with the companies, which are less than 500 , accounts for $55.1 \%$. The cooperation time of less than 10 years accounts for $81.1 \%$. Among the surveyed companies, $35.9 \%$ believe that the performance of cooperation with farmers remains unstable, $30.4 \%$ believe that both sides have established a long-term cooperative relationship, $33.2 \%$ believe that their trust has reached a certain level, and only $0.5 \%$ experienced dissatisfaction with the performance of the cooperation.

As shown in Table 2, farmers from Guangdong accounted for 34.1\%, and those from Hainan accounted for $65.9 \%$. The age group of the sample is mainly concentrated between 30 and 50 years of age $(61.5 \%)$ and those under 30 years old $(7.7 \%)$; hence, we can say that the proportion of young people engaged in agricultural production is progressively decreasing. The cooperation time of less than three years between farmers and the companies accounts for $47.8 \%$, indicating that most of the farmers and companies are in a relatively early stage of cooperation and mutual understanding. The farmers who said that the trust between each other had reached a certain level accounted for $49.8 \%$. 
Table 1. Statistics of the Basic Characteristics for Companies.

\begin{tabular}{|c|c|c|c|}
\hline \multirow{2}{*}{ Variables } & \multirow{2}{*}{ Value } & \multicolumn{2}{|c|}{$n=184$} \\
\hline & & Frequency & Percentage \\
\hline \multirow{2}{*}{ Region } & Guangdong & 108 & 58.7 \\
\hline & Hainan & 76 & 41.3 \\
\hline \multirow{5}{*}{$\begin{array}{l}\text { Number of } \\
\text { cooperative } \\
\text { farmers }\end{array}$} & $(0,50]$ & 53 & 29.5 \\
\hline & $(50,100]$ & 27 & 15.0 \\
\hline & $(100,500]$ & 19 & 10.6 \\
\hline & $(500,1000]$ & 61 & 33.9 \\
\hline & Above 1000 households & 20 & 11.0 \\
\hline \multirow{5}{*}{$\begin{array}{l}\text { Cooperation } \\
\text { Time (years) }\end{array}$} & $(0,1]$ & 13 & 7.2 \\
\hline & $(1,3]$ & 45 & 25.0 \\
\hline & $(3,5]$ & 28 & 15.6 \\
\hline & $(5,10]$ & 60 & 33.3 \\
\hline & above 10 years & 34 & 18.9 \\
\hline \multirow{5}{*}{$\begin{array}{c}\text { Cooperation } \\
\text { Stage }\end{array}$} & Unstable cooperation performance & 66 & 35.9 \\
\hline & Trust has reached a certain level & 61 & 33.2 \\
\hline & Have established a long-term relationship & 56 & 30.4 \\
\hline & Becoming dissatisfied with the cooperation & 1 & 0.5 \\
\hline & Have ended the cooperation or is in the process of ending it & 0 & 0 \\
\hline
\end{tabular}

Table 2. Statistics of the Basic Characteristics for Farmers.

\begin{tabular}{cccc}
\hline \multirow{2}{*}{ Variables } & Value & \multicolumn{2}{c}{$n=\mathbf{4 1 4}$} \\
\cline { 2 - 4 } Region & Guangdong & Frequency & Percentage \\
& Hainan & 141 & 34.1 \\
& $(0,30]$ & 273 & 65.9 \\
\hline \multirow{2}{*}{ Age } & $(30,40]$ & 28 & 7.7 \\
& $(40,50]$ & 78 & 21.4 \\
& Above 50 & 146 & 40.1 \\
Cooperation & $(0,1]$ & 112 & 30.8 \\
Time (years) & $(1,3]$ & 60 & 19.3 \\
& $(3,5]$ & 88 & 28.4 \\
& Above five years & 78 & 25.2 \\
Cooperation & Unstable cooperation performance & 84 & 27.1 \\
\hline Stage & Trust has reached a certain level & 51 & 15.5 \\
& Have established a long-term relationship & 89 & 49.8 \\
& Becoming dissatisfied with the cooperation & 8 & 27.1 \\
& Have ended the cooperation or is ending it & 17 & 2.4 \\
& & & 5.2 \\
\hline
\end{tabular}

\section{Analysis and Results}

\subsection{Reliability and Validity}

In this study, Cronbach's $\alpha$ value was utilized for internal consistency testing, as shown in Table 3. In Table 3, the Cronbach's $\alpha$ value of each factor in both samples is greater than 0.6, except the quality performance of agricultural products from farmers' perspective, which has a slightly lower value than 0.6. 
Table 3. Reliability Analysis.

\begin{tabular}{cccc}
\hline Construct & \multirow{2}{*}{ Item } & \multicolumn{2}{c}{ Cronbach's $\alpha$} \\
\cline { 3 - 4 } & & Company Perspective & Farmer Perspective \\
\hline Shared Values (SV) & 2 & 0.66 & 0.62 \\
Reciprocity (RE) & 4 & 0.80 & 0.74 \\
Communication (CO) & 4 & 0.86 & 0.81 \\
Quality Performance of agricultural products (QP) & 3 & 0.76 & 0.56 \\
\hline
\end{tabular}

The convergence validity of each variable was verified by confirmatory factor analysis. The results are shown in Tables 4 and 5. The data from both samples show that the factor loading of each variable is higher than 0.5 , indicating that each variable has good convergence validity.

Table 4. Confirmatory Factor Analysis for Companies.

\begin{tabular}{cccccc}
\hline Construct & Item & Factor Loading & Standard Deviation & $\boldsymbol{t}$-Value & $p$-Value \\
\hline \multirow{2}{*}{ Shared Values (SV) } & SV1 & 0.851 & 0.029 & 29.86 & $* * *$ \\
& SV2 & 0.883 & 0.021 & 42.92 & $* * *$ \\
\hline \multirow{2}{*}{ Reciprocity (RE) } & RE 1 & 0.778 & 0.041 & 18.89 & $* * *$ \\
& RE 2 & 0.802 & 0.035 & 22.66 & $* * *$ \\
& RE 3 & 0.819 & 0.026 & 31.84 & $* * *$ \\
& RE 4 & 0.768 & 0.031 & 24.93 & $* * *$ \\
\hline \multirow{2}{*}{ Communication (CO) } & CO1 & 0.725 & 0.038 & 19.28 & $* * *$ \\
& CO2 & 0.876 & 0.018 & 49.69 & $* * *$ \\
& CO3 & 0.864 & 0.021 & 40.49 & $* * *$ \\
Quality Performance of & CO4 & 0.877 & 0.020 & 44.40 & $* * *$ \\
agricultural products (QP) & QP1 & 0.884 & 0.018 & 49.81 & $* * *$ \\
& QP2 & 0.755 & 0.040 & 18.86 & $* * *$ \\
\hline
\end{tabular}

Note: ${ }^{* * *} p<0.001$.

Table 5. Confirmatory Factor Analysis for Farmers.

\begin{tabular}{|c|c|c|c|c|c|}
\hline Construct & Item & Factor Loading & Standard Deviation & $t$-Value & $p$-Value \\
\hline \multirow{2}{*}{ Shared Values (SV) } & SV1 & 0.851 & 0.029 & 29.86 & $* * *$ \\
\hline & SV2 & 0.883 & 0.021 & 42.92 & $* * *$ \\
\hline \multirow{4}{*}{ Reciprocity (RE) } & RE 1 & 0.778 & 0.041 & 18.89 & $* * *$ \\
\hline & RE 2 & 0.802 & 0.035 & 22.66 & $* * *$ \\
\hline & RE 3 & 0.819 & 0.026 & 31.84 & $* * *$ \\
\hline & RE 4 & 0.768 & 0.031 & 24.93 & $* * *$ \\
\hline \multirow{4}{*}{ Communication (CO) } & $\mathrm{CO} 1$ & 0.725 & 0.038 & 19.28 & $* * *$ \\
\hline & $\mathrm{CO} 2$ & 0.876 & 0.018 & 49.69 & $* * *$ \\
\hline & $\mathrm{CO} 3$ & 0.864 & 0.021 & 40.49 & $* * *$ \\
\hline & $\mathrm{CO} 4$ & 0.877 & 0.020 & 44.40 & $* * *$ \\
\hline \multirow{3}{*}{$\begin{array}{l}\text { Quality Performance of } \\
\text { agricultural products (QP) }\end{array}$} & QP1 & 0.884 & 0.018 & 49.81 & $* * *$ \\
\hline & QP2 & 0.755 & 0.040 & 18.86 & $* * *$ \\
\hline & QP3 & 0.834 & 0.024 & 35.03 & $* * *$ \\
\hline
\end{tabular}

Note: ${ }^{* * *} p<0.001$.

The premise to verify the discriminant validity is that the square root of the average variance extracted (AVE) value of each variable is greater than the correlation coefficient between it and other variables [41]. The data presented diagonally in Tables 6 and 7 are the AVE square root values of each variable, and the others are the correlation coefficients between the variables. As can be seen in the two 
tables, the AVE square root of each variable is greater than the correlation coefficient value between it and other variables, indicating that the measurement has good discriminant validity.

Table 6. Discriminant Validity Analysis for Companies.

\begin{tabular}{lcccc}
\hline & $\mathbf{1}$ & $\mathbf{2}$ & $\mathbf{3}$ & $\mathbf{4}$ \\
\hline 1. Shared Values (SV) & $\mathbf{0 . 8 7}$ & & & \\
2. Communication (CO) & 0.68 & $\mathbf{0 . 8 4}$ & & \\
3. Reciprocity (RE) & 0.57 & 0.71 & $\mathbf{0 . 7 9}$ & \\
4. Quality Performance of agricultural products (QP) & 0.59 & 0.74 & 0.72 & $\mathbf{0 . 8 3}$ \\
\hline
\end{tabular}

Note: The matrix is marked in bold, displayed as the square root of AVE on the diagonal; the other data are the correlation coefficient between variables.

Table 7. Discriminant Validity Analysis for Farmers.

\begin{tabular}{lcccc}
\hline & $\mathbf{1}$ & $\mathbf{2}$ & $\mathbf{3}$ & $\mathbf{4}$ \\
\hline 1. Shared Values (SV) & $\mathbf{0 . 8 5}$ & & & \\
2. Communication (CO) & 0.61 & $\mathbf{0 . 8 0}$ & & \\
3. Reciprocity (RE) & 0.58 & 0.60 & $\mathbf{0 . 7 4}$ & \\
4. Quality Performance of agricultural products (QP) & 0.51 & 0.42 & 0.61 & $\mathbf{0 . 7 4}$ \\
\hline
\end{tabular}

Note: The matrix is marked in bold and displayed as the square root of AVE on the diagonal; the other data are the correlation coefficient between variables.

\subsection{Hypothesis Testing and Results}

Smart PLS 2.0 was utilized to test the relationship among shared values, communication, reciprocity, and quality performance of agricultural products. Figures 2 and 3 illustrate the standard path coefficients and $p$-value. The results of hypotheses testing are shown in Table 8. Figures 2 and 3 show the statistical results of our analysis. The reciprocal $\mathrm{R}^{2}$ values are $51.4 \%$ from companies' perspective and $43.5 \%$ from farmers' perspective. The $\mathrm{R}^{2}$ values for quality performance of agricultural products are $63.2 \%$ from companies' perspective and $40.7 \%$ from farmers' perspective, respectively. The results indicate that the variance of reciprocity and quality performance of agricultural products can be supported by the social exchange theory we proposed. Table 8 shows that H1a, H1b, H2b, and $\mathrm{H} 2 \mathrm{c}$ from the company perspective are supported, while $\mathrm{H} 2 \mathrm{a}$ is not supported. Meanwhile, it shows that $\mathrm{H} 1 \mathrm{a}, \mathrm{H} 1 \mathrm{~b}, \mathrm{H} 2 \mathrm{a}$, and $\mathrm{H} 2 \mathrm{~b}$ from the farmer's perspective are all supported, while $\mathrm{H} 2 \mathrm{c}$ is not supported.

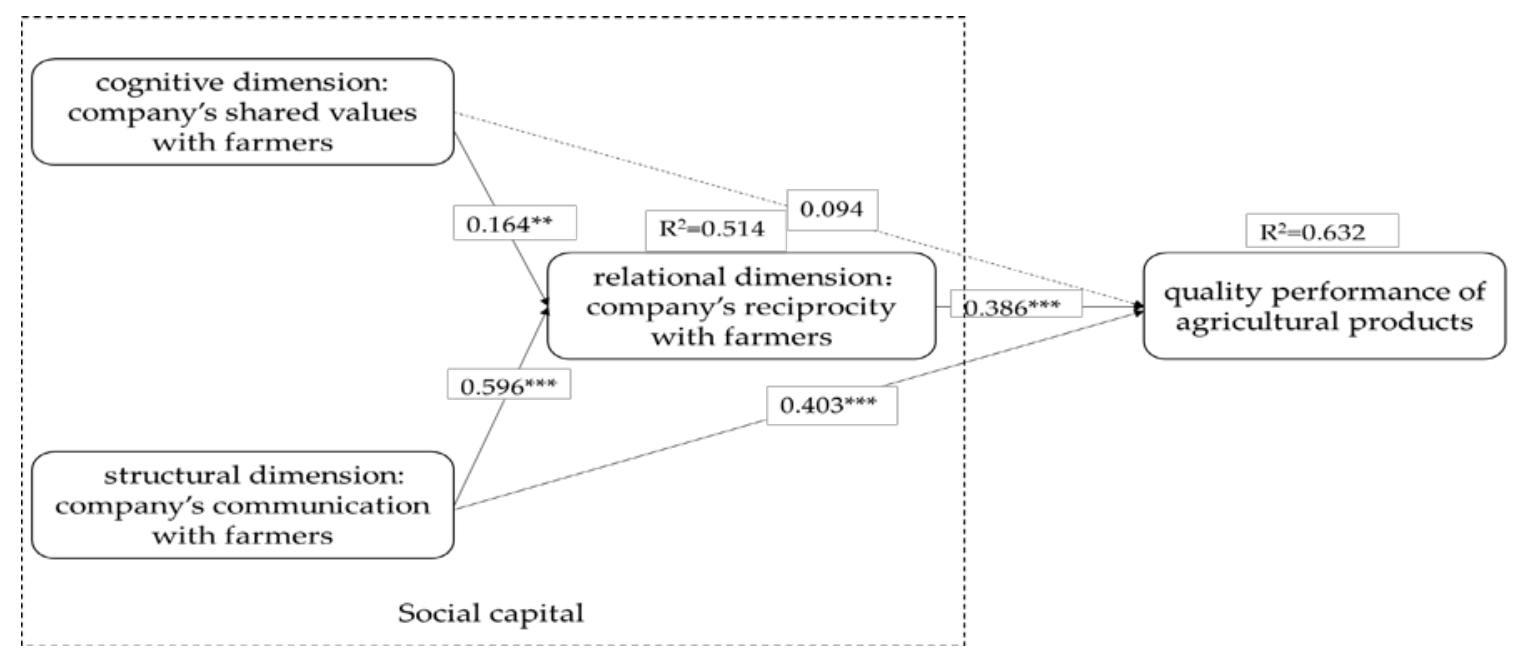

Figure 2. Structural Equation Model of Companies. Note: ${ }^{* *} p<0.01,{ }^{* * *} p<0.001$. 


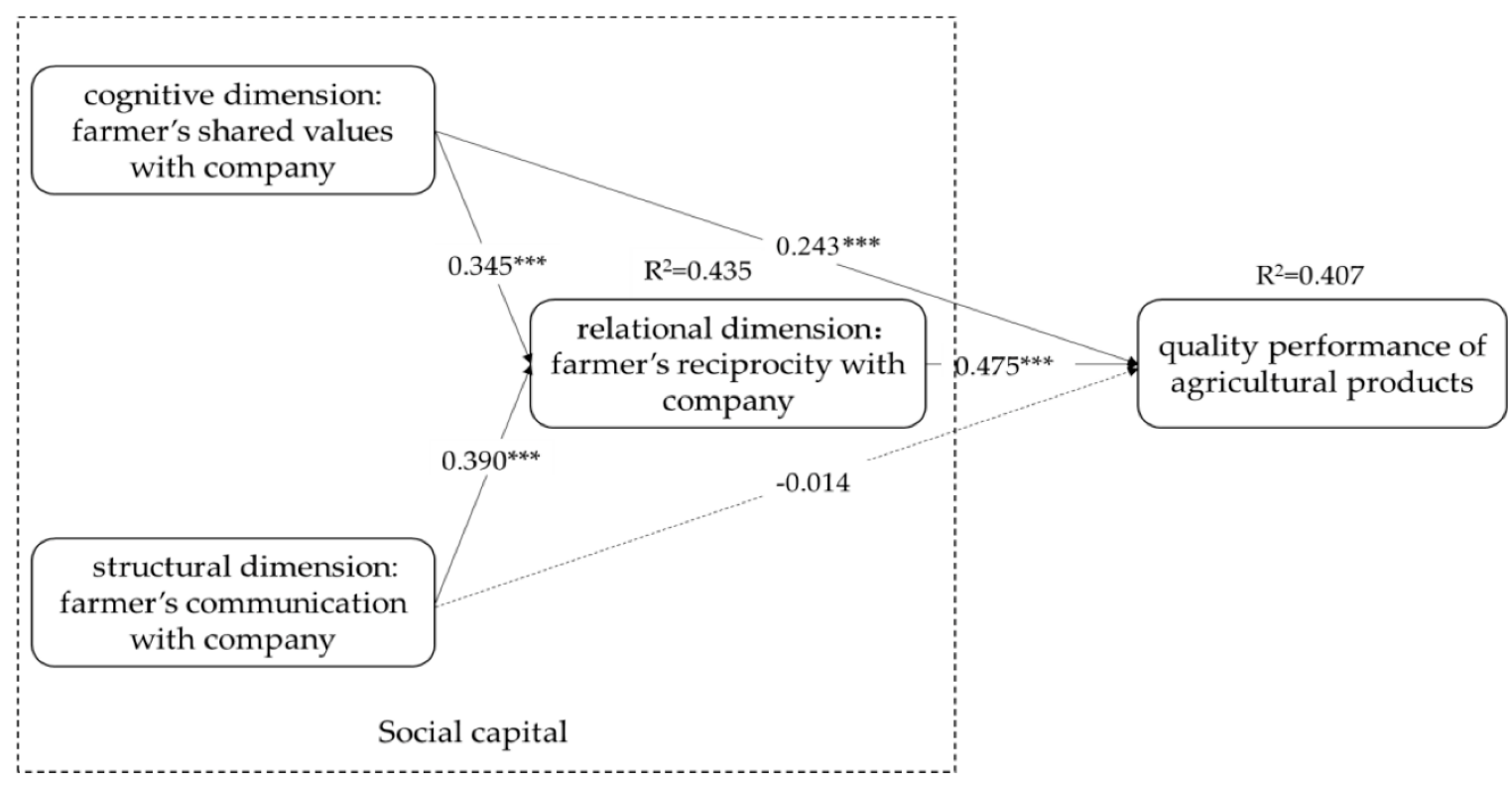

Figure 3. Structural Equation Model of Farmers. Note: ${ }^{* *} p<0.001$.

Table 8. Results of Hypotheses Testing.

\begin{tabular}{lcccc}
\hline \multirow{2}{*}{ Hypotheses } & \multicolumn{2}{c}{ Companies' Perspective } & \multicolumn{2}{c}{ Farmers' Perspective } \\
\cline { 2 - 5 } & $t$-Value & Outcome & $t$-Value & Outcome \\
\hline H1a: shared values-> reciprocity (+) & 2.36 & Supported & 5.97 & Supported \\
\hline H1b: communication-> reciprocity (+) & 11.49 & Supported & 6.68 & Supported \\
\hline $\begin{array}{l}\text { H2a: shared values-> quality } \\
\text { performance of agricultural products (+) }\end{array}$ & 1.12 & Rejected & 4.27 & Supported \\
\hline $\begin{array}{l}\text { H2b: reciprocity-> quality performance of } \\
\text { agricultural products (+) }\end{array}$ & 6.72 & Supported & 8.35 & Supported \\
\hline $\begin{array}{l}\text { H2c: communication-> quality } \\
\text { performance of agricultural products }(+)\end{array}$ & 4.28 & Supported & 0.21 & Rejected \\
\hline
\end{tabular}

\section{Discussion}

\subsection{Promoting Relational Dimension through Cognitive and Structural Dimensions}

The empirical results from the perspectives of companies and farmers show that the shared values (company: $\beta=0.164, p<0.01$; farmer: $\beta=0.345, p<0.001$ ) and communication (company: $\beta=0.596, p<0.001$; farmer: $\beta=0.390, p<0.001$ ) have a significant positive impact on reciprocity, indicating that both $\mathrm{H} 1 \mathrm{a}$ and $\mathrm{H} 1 \mathrm{~b}$ are supported. This result supports that both cognitive and structural dimensions have a positive impact on the relational dimension, consistent with the empirical results of Carey et al. [6] and Horn et al. [25]. This finding also shows that companies or farmers with shared values and good communication would tend to conduct mutually reciprocal behaviors towards each other in cooperation.

Moreover, in terms of the degree of influence on reciprocity, regardless of whether from the companies' perspective or the farmers' perspective, communication is higher than the shared values, further demonstrating that communication is a priority in fostering reciprocity. 


\subsection{Promoting Quality Performance of Agricultural Products through Social Capital}

The empirical results show that the three dimensions of social capital (shared values, reciprocity, communication) have different effects on quality performance of agricultural products. From the companies' perspective, reciprocity $(\beta=0.386, p<0.001)$ and communication $(\beta=0.403, p<0.001)$ have a significant positive effect on the quality performance of agricultural products. Thus, while $\mathrm{H} 2 \mathrm{~b}$ and $\mathrm{H} 2 \mathrm{c}$ are supported, $\mathrm{H} 2 \mathrm{a}$ is not supported. From the farmers' perspective, the shared values ( $\beta=0.243, p<0.001)$ and reciprocity $(\beta=0.475, p<0.001)$ have a significant positive effect on the quality performance of agricultural products; thus, $\mathrm{H} 2 \mathrm{a}$ and $\mathrm{H} 2 \mathrm{~b}$ are supported, while $\mathrm{H} 2 \mathrm{c}$ is not supported. This result is different from the result of Yim and Leem [18] who reported that the three dimensions of social capital positively affect performance. However, that study only empirically explored the company's economic performance and used just one item to measure quality performance.

Interestingly, the empirical results show that the impacts of different dimensions of social capital on quality performance of agricultural products vary between the two perspectives. From the companies' perspective, the effect on the quality performance of agricultural products is ordered as follows: communication > reciprocity; whereas from the farmers' side, the order of effect is as follows: reciprocity $>$ shared values. That is, from the farmers' perspective, the role of reciprocity on quality performance of agricultural products is significantly higher than shared values. The likely reason for this difference in ranking is that Chinese farmers remain in a state of scarcity and reciprocity may be practical for them. On the company side, communication plays an important role, possibly because the companies have invested more resources in the cooperation process, such as equipment and technology. For these resources to be fully functioning, they need to communicate with farmers frequently to ensure that farmers who have low education level can develop production technology skills. Therefore, the companies maintaining a high level of communication with farmers can effectively avoid the quality problem of primary agricultural products in the production process.

At the same time, this study finds that reciprocity has a significant positive effect on the quality performance of agricultural products, both from the perspective of the companies and the perspective of farmers, which also shows the importance of reciprocity in Chinese culture. There is an old saying in China: "a drop of water in need shall be returned with a spring in deed", which means that when someone gives you a little help, you should keep it in mind and return twice as much. Otherwise you will be regarded as "faithless" and "looked down upon" and lose "face". This is the value of reciprocity in Chinese relations. Therefore, in the process of cooperation, due to the "reciprocity of courtesy" in Chinese rural social culture, "respect from others, respect from others" and "courtesy from others", favored farmers would be more willing to match production in return, thus guaranteeing the quality performance of the company's agricultural products.

\section{Conclusions}

This study empirically explores the relationship between the three dimensions of social capital (shared values, communication, reciprocal) and their role in the quality performance of agricultural products. The empirical results reveal that both shared values and communication have significant positive effects on reciprocity, and reciprocity has a significant positive effect on the quality performance of agricultural products. In terms of the degree of influence on reciprocity, from the perspectives of both the companies and the farmers, communication is higher than shared values. Therefore, to improve the quality performance of agricultural products, fostering reciprocity between the companies and the farmers is highly recommended.

\subsection{Theoretical Contributions and Managerial Implications}

The theoretical contributions of this research are two-fold. (1) From the binary perspective of companies and farmers- the empirical exploration of the relationship between the three dimensions of social capital is helpful in understanding the interaction path among different dimensions of 
social capital, allowing us to gain a profound understanding of individual and collective social capital while enriching the literature on social capital theory. (2) From the binary perspective of companies and farmers, the empirical exploration of the relationship between social capital and quality performance of agricultural products is helpful in understanding the mechanism of each dimension of social capital and how they affect quality performance of agricultural products, thus enriching buyer-seller relationship management theory in the fields of operational management and supply chain management. The results have positive managerial implications and policy implications for improving the quality performance of agricultural products and promoting the "Belt and Road" strategy. The management implications for companies and farmers are as follows:

(1) To improve the quality performance of agricultural products, company managers or farmers should prioritize the accumulation of social capital. When the resources are limited, the order of cultivation of the company's social capital is communication first followed by reciprocity; for farmers, it should be reciprocity first followed by shared values. In general, the company is in a leading position in the cooperation, it has the responsibility for helping farmers cultivate social capital, such as making farmers feel obliged towards reciprocity by making profits or helping them survive difficult times. Through regular or irregular events, the company can foster shared values with the farmers and actively build various information channels to understand the voices of farmers and discover problems of farmers.

(2) Companies or farmers can foster reciprocal behaviors through communication and shared values. Therefore, the companies should communicate with farmers and build shared values through different channels, such as regular symposia, important event launches or through public channels to showcase the propaganda of traditional virtue education, typical figures, willingness to help others, and common prosperity, thereby creating a good atmosphere of mutual assistance. Companies can also arrange technical staff to conduct regular visits to farmers and help them organize rich community cultural activities. Alternatively, companies can build a platform for farmers to communicate and encourage information exchange between farmers, such as through cultural activities like traditional festivals, fun competitions related to agriculture during the slack seasons, a championship system, and so on. For farmers, they had better be actively engaged in the various channels provided by companies.

For the government, it is suggested to introduce the governance of the relationship between the company and farmers as the indicator of leading companies in the assessment, such as the inclusion of evaluation indicators including reciprocity, shared values, etc., so as to guide the company to actively cultivate social capital with farmers and improve the quality of primary agricultural products. Also, since government transparency plays a significant role to promote accountability and prevent maladministration, it is important for the government to produce proper tools to assess and compare government transparency practices in agricultural product management [42]. In addition, to further promote government regulation, the application of performance assessment systems such as the innovative performance assessment system suggested by Pinto et al. [38] can be applied to improve efficiency for quality improvements.

\subsection{Future Research}

Although this study has contributions to theory and practice, it also has limitations. First of all, owing to the limitations of data acquisition, this study only selected samples from two regions of China, namely, Guangdong and Hainan. These samples could not completely replace the full view of the $\mathrm{C}+\mathrm{F}$ alliance in China. In the future, additional samples need to be collected from different regions of China to further analyze and popularize the research conclusions. Secondly, this study uses cross-sectional data to conduct an empirical model test, and the result only has limited persuasiveness. In fact, the effect of social capital on performance tends to change over time. Therefore, in the long run, the role of social capital in quality performance of agricultural products may be more pronounced than before. In the future, further expanding the longitudinal time series analysis and collection of 
bilateral pairing data can help increase the reliability of the results. Thirdly, the three dimensions of social capital can also be subdivided. For example, the relational dimension can add trust, relationship commitment, and so on; the cognitive dimension can add shared goals and common vision, common norms, etc.; and the structural dimension can add social interaction, information sharing, and so on. In the future, we can continue to subdivide the dimensions for exploration so that the empirical results can clearly explain the relationships among these dimensions.

Author Contributions: Conceptualization, S.F.; Data curation, S.F. and W.Q.; Formal analysis, H.L. and Y.D.; Funding acquisition, S.F.; Investigation, S.F.; Methodology, H.L.; Software, Y.D.; Supervision, S.F.; Writing—original draft, H.L. and W.Q.; Writing-review \& editing, K.H.T. and Y.Z.

Acknowledgments: This research was supported by the National Social Science Fund of China (16BGL128).

Conflicts of Interest: The authors declare no conflict of interest.

\section{Appendix A. Questionnaire Items}

\section{Companies' perspective:}

Shared values with farmers (Adapted from Kale et al. [43], Gelderman et al. [10])

SV1: The company has identified with the farmers' production methods

SV2: The company feels that the farmers consider them as its "important member of the team" and not just a buyer

Reciprocity with farmers (Adapted from Nahapiet and Ghoshal [17], Krause et al. [24])

RE1: When the situation changes, the farmers are likely to give the company maximum assistance

RE2: The cooperation with farmers has reduced the company' s fixed assets investment

RE3: The cooperation with farmers has cut the company' s capital investment

RE4: The company usually obtains good advice from farmers

Communication with farmers (Adapted from Huo et al. [31], Fu et al. [44])

$\mathrm{CO} 1$ : When the situation changes, the farmers are likely to give the company maximum assistance CO2: The cooperation with farmers has reduced the company's fixed assets investment

CO3: The cooperation with farmers has cut the company's capital investment

CO4: The company usually obtains good advice from farmers

Quality performance of agricultural products (Adapted from Huo et al. [40], Fu et al. [1])

QP1: The cooperation with farmers has improved the production quality

QP2: The company's rejection rate for agricultural products produced by farmers is very low

QP3: The cooperation with the farmers has improved the production capacity of the company

\section{Farmers' perspective:}

Shared values with the company (Adapted from Kale et al. [43], Gelderman et al. [10])

SV1: The farmers have identified with the company's management method

SV2: The farmers feel that the company consider them as its "important member of the team" and not just producers

Reciprocity with the company (Adapted from Nahapiet and Ghoshal [17], Krause et al. [24])

RE1: When the situation changes, the company is likely to give the farmers maximum assistance

RE2: The cooperation with the company has reduced the farmers' fixed assets investment

RE3: The cooperation with the company has cut the farmers' capital investment

RE4: The farmers usually obtain good advice from the company

Communication with the company (Adapted from Huo et al. [31], Fu et al. [44])

CO1: Both sides have assigned dedicated personnel to coordinate communication

$\mathrm{CO}$ : The farmers often conduct face-to-face exchanges and cooperation with the company 
CO3: When conflicts and misunderstandings occur during the process of cooperation, both sides can patiently solve them

CO4: Both sides can provide timely information to help each other

Quality performance of agricultural products (Adapted from Huo et al. [40], Fu et al. [1])

QP1: The cooperation with the company has improved the production quality

QP2: The company's rejection rate for agricultural products produced by farmers is very low

QP3: The cooperation with the company has improved the production capacity of the farmers

\section{References}

1. Fu, S.L.; Zhan, Y.Z.; Tan, K.H. Managing social responsibility in Chinese agriculture supply chains through the "a company + farmers" model. Eur. Bus. Rev. 2017, 29, 344-359. [CrossRef]

2. Jia, X.P.; Bijman, J.; Silva, C.; Ranking, M. Contract farming: Synthetic themes for linking farmers to demanding markets. In Contract Farming for Inclusive Market access; Da Silva, C.A., Rankin, M., Eds.; FAO: Rome, Italy, 2014; pp. 21-38.

3. Johnson, N.L.; Suarez, R.; Lundy, M. The importance of social capital in Colombian rural agro-enterprises. In Proceedings of the 25th International Conference on Agriculture Economic (IAAE), Event Dynamics, Durban, Africa, 16-22 August 2003; pp. 1152-1158.

4. Lin, C.S.; Chang, R.Y.; Dang, V.T. An integrated model to explain how corporate social responsibility affects corporate financial performance. Sustainability 2015, 7, 8292-8311. [CrossRef]

5. Park, H.; Tsusaka, T.W.; Pede, V.O.; Kim, K.M. The Impact of a Local Development Project on Social Capital: Evidence from the Bohol Irrigation Scheme in the Philippines. Water 2017, 9, 202. [CrossRef]

6. Carey, S.; Lawson, B.; Krause, D.R. Social capital configuration, legal bonds and performance in buyer-supplier relationships. J. Oper. Manag. 2011, 29, 277-288. [CrossRef]

7. Dyer, J.H.; Nobeoka, K. Creating and managing a high-performance knowledge-sharing network: The Toyota case. Strateg. Manag. J. 2000, 21, 345-367. [CrossRef]

8. Koka, B.R.; Prescott, J.E. Strategic alliances as social capital: A multidimensional view. Strateg. Manag. J. 2002, 23, 795-816. [CrossRef]

9. Villena, V.H.; Revilla, E.; Choi, T.Y. The dark side of buyer-supplier relationships: A social capital perspective. J. Oper. Manag. 2011, 29, 561-576. [CrossRef]

10. Gelderman, C.J.; Semeijin, J.; Mertschuweit, P.P. The impact of social capital and technological uncertainty on strategic performance: The supplier perspective. J. Purch. Supply Manag. 2016, 22, 225-234. [CrossRef]

11. Johnson, N.; Elliott, D.; Drake, P. Exploring the role of social capital in facilitating supply chain resilience. Supply Chain Manag. Int. J. 2013, 18, 324-336. [CrossRef]

12. Schiele, H.; Ellis, S.C.; Ebig, M.; Henke, J.W.; Kull, T.J. Management supplier satisfaction: Social capital and resource dependence frameworks. Australas. Mark. J. 2015, 23, 132-138. [CrossRef]

13. Lee, $\mathrm{S}$. The effects of green supply chain management on the supplier's performance through social capital accumulation. Supply Chain Manag. Int. J. 2015, 20, 42-55. [CrossRef]

14. Chu, S.H.; Yang, H.; Lee, M.; Park, S. The impact of institutional pressures on green supply chain management and firm performance: Top management roles and social capital. Sustainability 2017, 9, 764. [CrossRef]

15. Farooq, U.; Tao, W.; Alfian, G.; Kang, Y.S.; Rhee, J. ePedigree traceability system for the agricultural food supply chain to ensure consumer health. Sustainability 2016, 8, 839. [CrossRef]

16. Tan, K.; Shi, L.; Tseng, M.; Chiu, A. Managing the indirect effects of environmental regulation and performance measurement. Ind. Eng. Manag. Syst. 2014, 13, 148-153. [CrossRef]

17. Nahapiet, J.; Ghoshal, S. Social capital, intellectual capital and the organizational advantage. Acad. Manag. Rev. 1998, 23, 242-266. [CrossRef]

18. Yim, B.; Leem, B. The effect of the supply chain social capital. Ind. Manag. Data Syst. 2013, 113, 324-349. [CrossRef]

19. Li, Y.N.; Ye, F.; Sheu, C. Social capital, information sharing and performance: Evidence from china. Int. J. Oper. Prod. Manag. 2014, 34, 1440-1462. [CrossRef]

20. Inkpen, A.C.; Tsang, E.W.K. Social capital, networks, and knowledge transfer. Acad. Manag. Rev. 2005, 30, 146-165. [CrossRef] 
21. Burt, R.S. Structural Holes: The Social Structure of Competition; Harvard University Press: Cambridge, MA, USA, 1992.

22. Coleman, J.S. Foundations of Social Theory; The Belknap Press of Harvard University Press: Cambridge, MA, USA, 1990.

23. Maurer, I.; Ebers, M. Dynamics of social capital and their performance implications: Lessons from biotechnology start-ups. Adm. Sci. Q. 2006, 51, 262-292. [CrossRef]

24. Krause, D.R.; Handfield, R.B.; Tyler, B.B. The relationships between supplier development, commitment, social capital accumulation and performance improvement. J. Oper. Manag. 2007, 25, 528-545. [CrossRef]

25. Horn, P.; Scheffler, P.; Schiele, H. Internal integration as a pre-condition for external integration in global sourcing: A social capital perspective. Int. J. Prod. Econ. 2014, 153, 54-65. [CrossRef]

26. Roden, S.; Lawon, B. Developing social capital in buyer-supplier relationships: The contingent effect of relationship-specific adaptations. Int. J. Prod. Econ. 2014, 151, 89-99. [CrossRef]

27. Ouchi, W.G. Markets, bureaucracies, and clans. Adm. Sci. Q. 1980, 25, 129-141. [CrossRef]

28. Tsai, W.; Ghoshal, S. Social capital and value creation: The role of intrafirm networks. Acad. Manag. J. 1998, 41, 464-476.

29. Sheng, S.; Brown, J.R.; Nicholson, C.Y.; Poppo, L. Do exchange hazards always foster relational governance? An empirical test of the role of communication. Int. J. Res. Market. 2006, 23, 63-77. [CrossRef]

30. Mohr, J.; Spekman, R. Characteristics of partnership success: Partnership attributes, communication behavior, and conflict resolution techniques. Strateg. Manag. J. 1994, 15, 135-152. [CrossRef]

31. Huo, B.F.; Wang, Z.Q.; Tian, Y. The impact of justice on collaborative and opportunistic behaviors in supply chain relationships. Int. J. Prod. Econ. 2016, 177, 12-23. [CrossRef]

32. Grover, V.; Malhotra, M.K. Transaction cost framework in operations and supply chain management research: Theory and measurement. J. Oper. Manag. 2003, 21, 457-473. [CrossRef]

33. Lei, D.; Slocum, J.W., Jr.; Pitts, R.A. Building cooperative advantage: Managing strategic alliances to promote organizational learning. J. World Bus. 1997, 32, 203-223. [CrossRef]

34. Putnam, R.D. The prosperous community: Social capital and public life. Am. Prospect 1993, 13, 35-42.

35. Portes, A. Social capital: Its origins and applications in modern sociology. Annu. Rev. Sociol. 1998, $24,1-24$. [CrossRef]

36. Dyer, J.H.; Chu, W. The role of trustworthiness in reducing transaction costs and improving performance: Empirical evidence from the United States, Japan, and Korea. Organ. Sci. 2003, 14, 57-68. [CrossRef]

37. Perrone, V.; Zaheer, A.; Mcevily, B. Free to be trusted? Organizational constraints on trust in boundary spanners. Organ. Sci. 2003, 14, 422-439. [CrossRef]

38. Pinto, F.S.; Simões, P.; Marques, R.C. Raising the bar: The role of governance in performance assessments. Util. Policy 2017, 49, 38-47. [CrossRef]

39. Carr, A.S.; Pearson, J.N. Strategically managed buyer-supplier relationships and performance outcomes. J. Oper. Manag. 1999, 17, 497-519. [CrossRef]

40. Huo, B.F.; Zhao, X.D.; Lai, F. Supply chain quality integration: Antecedents and consequences. IEEE. Trans. Eng. Manag. 2014, 61, 38-51. [CrossRef]

41. Fornell, C.; Larcker, D.F. Evaluating structural equation models with unobservable variables and measurement Error. J. Market. Res. 1981, 18, 39-50. [CrossRef]

42. Da Cruz, N.F.; Tavares, A.F.; Marques, R.C.; Jorge, S.; de Sousa, L. Measuring local government transparency. Public Manag. Rev. 2016, 18, 866-893. [CrossRef]

43. Kale, P.; Singh, H.; Perlmutter, H. Learning and protection of proprietary assets in strategic alliances: Building relational capital. Strateg. Manag. J. 2000, 21, 217-237. [CrossRef]

44. Fu, S.L.; Li, Z.W.; Wang, B.; Han, Z.J.; Huo, B.F. Cooperative behavior between companies and contract farmers in Chinese agricultural supply chains: Relational antecedents and consequences. Ind. Manag. Data Syst. 2018, 118, 1033-1051. [CrossRef]

(c) 2018 by the authors. Licensee MDPI, Basel, Switzerland. This article is an open access article distributed under the terms and conditions of the Creative Commons Attribution (CC BY) license (http:/ / creativecommons.org/licenses/by/4.0/). 